IZA DP No. 5418

Income Pooling and Household Division of Labor: Evidence from Danish Couples

Catalina Amuedo-Dorantes

Jens Bonke

Shoshana Grossbard

December 2010 


\title{
Income Pooling and Household Division of Labor: Evidence from Danish Couples
}

\author{
Catalina Amuedo-Dorantes \\ San Diego State University \\ and IZA
}

Jens Bonke

Rockwool Foundation, Denmark

Shoshana Grossbard

San Diego State University

and IZA

\author{
Discussion Paper No. 5418 \\ December 2010
}

\author{
IZA \\ P.O. Box 7240 \\ 53072 Bonn \\ Germany \\ Phone: +49-228-3894-0 \\ Fax: +49-228-3894-180 \\ E-mail: iza@iza.org
}

Any opinions expressed here are those of the author(s) and not those of IZA. Research published in this series may include views on policy, but the institute itself takes no institutional policy positions.

The Institute for the Study of Labor (IZA) in Bonn is a local and virtual international research center and a place of communication between science, politics and business. IZA is an independent nonprofit organization supported by Deutsche Post Foundation. The center is associated with the University of Bonn and offers a stimulating research environment through its international network, workshops and conferences, data service, project support, research visits and doctoral program. IZA engages in (i) original and internationally competitive research in all fields of labor economics, (ii) development of policy concepts, and (iii) dissemination of research results and concepts to the interested public.

IZA Discussion Papers often represent preliminary work and are circulated to encourage discussion. Citation of such a paper should account for its provisional character. A revised version may be available directly from the author. 
IZA Discussion Paper No. 5418

December 2010

\section{ABSTRACT \\ Income Pooling and Household Division of Labor: Evidence from Danish Couples}

If income pooling indicates primary earners' willingness to trade part of their income with spouses who earn less and work more in household production, then among specialized couples income pooling will be positively associated with the price of commercial domestic services, substitutes for household production. In line with our prediction, analyses of data from a unique Danish household survey show that complete income pooling is more frequent where commercial domestic services are more expensive.

\section{NON-TECHNICAL SUMMARY}

We find that the higher the wage of unskilled female workers in the region of residence - our proxy for the price of commercial domestic services - the more couples are likely to completely share their income. This finding is limited to specialized couples along traditional gender lines. Our finding suggests that where women perform home production in excess of what their husbands (or partners) do, they get compensated for this extra work in the form of access to extra income earned by their husbands.

JEL Classification: D13, D14, J12

Keywords: home production, income pooling, household finance, domestic services

Corresponding author:

Shoshana Grossbard

Department of Economics

San Diego State University

San Diego, CA 92182-4485

USA

E-mail: shosh@mail.sdsu.edu

\footnotetext{
* Helpful comments were received from Libertad Gonzalez, Robert Lerman, David Margulies, JeanMarc Robin, Almudena Sevilla-Sanz and participants in seminars at M.I.T., Sorbonne-Paris I, Tilburg University, the University of Zaragoza, and ZEW in Mannheim.
} 


\section{Introduction}

Most of the economic literature on consumption and savings views households as merged decision-making units with shared preferences and pooled incomes. Among those who have challenged this simplistic view of the household on conceptual grounds and recognized that individual household members may differ in their preferences are Samuelson (1956), McElroy and Horney (1981), Grossbard (1984), Apps and Rees (1988, 1997), Chiappori (1992), Lundberg and Pollak (1993), Browning et al (1994), and Chen and Woolley (2001). In addition, a number of empirical studies have shown that the earner's identity affects consumption decisions (e.g. Thomas 1990, Browning et al 1994, Lundberg, Pollak and Wales 1997, Phipps and Burton 1998, Lee 2007), suggesting that couples fail to completely pool their incomes. Furthermore, it has been documented that individuals living together in unmarried cohabitation (for short, cohabitation) or marriage often keep separate bank accounts in the U.S. (Treas 1993 and Klawitter 2008) and Canada (Woolley 2003). Using the Danish Household Survey of 19992005, which specifically asks respondents whether they pool their incomes, Bonke and UldallPoulsen (2007; hence BU) find that complete income pooling is far from universal. In yet other countries, financial independence in marriage is commanded by law. In that regard, Korean law requires that married Koreans hold separate savings accounts (Lee and Pocock 2007).

Explanations of financial pooling by couples have focused on the existence of public goods ${ }^{2}$ or on bargaining over financial control based on the resources owned by each partner. ${ }^{3}$ Less attention has been paid to specialization in household production as an explanation for

\footnotetext{
${ }^{2}$ For instance, it has been shown that couples are less likely to have separate accounts (Treas 1993, Klawitter 2008) if they have more children, which are considered as household public goods (defined by Lam 1988). Likewise, BU showed that couples with children are more likely to pool their incomes.

${ }^{3}$ In line with household bargaining theories (e.g. McElroy and Horney (1981) or Lundberg and Pollak (1993)), Treas (1993), Chen and Woolley (2001) and other sociological research surveyed by Klawitter (2008) report that women more active in the labor force are more likely to have their own bank accounts. Similarly, Lee and Pocock (2007) show that the higher wives' relative earnings are in Korea, the more they are likely to have savings on their name.
} 
income pooling. Exceptions are Dobbelsteen and Kooreman (1997) and BU, who recognize that the incentive for income pooling can derive from the perceived gains from specialization. We add to the existing literature by modeling and empirically testing whether income pooling serves as a form of intra-household compensation by the couple's principal earner to the couple's likely main supplier of household work.

Like the afore-mentioned literature, we assume that income pooling depends on the existence of public goods and that partners bargain over financial control. However, our approach differs in that we assume that bargaining over who controls the finances is a function not only of the resources that each individual owns, but also of the division of labor among the two partners. Specifically, we posit that income pooling is partially a form of compensation to the spouse likely specializing in household production. We view such an exchange of work for money within the household as reminiscent of an exchange of work for a wage in the labor market in more than one way. Competitive markets help establish equilibrium terms of trade for work in household production in a manner similar to how labor supply and demand determine equilibrium wages in labor market. Those terms of trade influence intra-household specialization and the likelihood of income pooling.

We analyze data from a Danish survey on income pooling, a unique component of the 1999-2005 Danish Household Survey that has been previously analyzed by BU (2007) and Bonke and Browning (2010). We offer empirical evidence that supports our interpretation of income pooling possibly serving as compensation from primary earners to secondary earners in exchange for their presumably greater specialization in household work. Specifically, we find that an increase in the wages of unskilled female workers -our proxy for the price of commercial domestic services, which can be considered a substitute for home production by one of the 
partners- raises the likelihood of income pooling among couples with traditional specialization following gender lines. However, it has no effect on the likelihood of income pooling among other couples. This is consistent with our view of income pooling as a channel that facilitates compensation by one spouse for the work performed by the other spouse in household production.

\section{Conceptual Framework}

Our goal is to gain a better understanding of why some couples pool their incomes and others do not. We assume that individuals remain independent decision-making agents after entering marriage or cohabitation, implying that they each have their own monetary disposable personal income. Disposable Personal Income (DPI) is defined as:

$$
D P I_{i}=M I_{i}+T_{i},
$$

that is, the sum of own monetary income $(M I)$ and an intra-household transfer $T$ paid to partner $i$ by partner $j .{ }^{4}$ In the case where partners have equal incomes, $T=0$, i.e. income pooling does not involve transfers from a primary to a secondary earner. However, if the spouses' incomes differ, income pooling involves a transfer from the primary earner $(T<0)$ to the secondary earner $(T>$ 0). We further assume that transfers are a function of the housework performed by the secondary earner.

We distinguish between specialized and non-specialized households. For the purpose of this conceptual framework, specialized households are households where one partner is more active in labor market production and also earns more than the other. ${ }^{5}$ In specialized households,

\footnotetext{
${ }^{4}$ We use the terms 'partner' and 'spouse' interchangeably, as for most of our discussion it does not matter if partners are married or cohabit.

${ }^{5}$ A more precise definition of what specialized couples look like in the empirical analysis is provided in the Data section.
} 
$T$ is a function of hours of housework and the value of an hour of household work and is given

by:

$$
T=h y,
$$

where $h$ stands for hours of work spent in household production by the secondary earner. This includes chores such as meal preparation, laundry, and home cleaning. In turn, $y$ is the hourly compensation agreed upon by the spouses implicitly or explicitly. This "wage" $y$ is likely to be influenced by equilibrium conditions in local marriage markets. ${ }^{6}$ Income pooling is then a function of how much housework $h$ the secondary earner actually performs and of how much $y$ the primary earner actually pays per hour of the spouse's household work.

Our main objective is to determine whether specialized couples pool their incomes as a form of compensation for the household work performed by secondary earners. To that end, we examine whether such compensation rises when the cost of a close substitute for household production by a partner, as is the case with commercial domestic services, goes up. The higher the value of the price of domestic services in a couple's area of residence, the lower the demand for commercial domestic services by the primary earner and the higher the demand for household work performed by the secondary earner in specialized couples $(h)$. Increased demand for household production by a partner will, in turn, raise $T$ by raising $h$ and/or its value, $y:^{7}$

$$
T=h(X) * y(X)
$$

\footnotetext{
${ }^{6}$ It is reminiscent of the concept of 'quasi-wage' in Grossbard-Shechtman (1993).

${ }^{7}$ If the price of domestic services in a couple's area of residence increases, the aggregate demand for secondary earners' $h$ will increase. If only the demand shifts, it will result in higher compensation for secondary earners performing domestic work in marriage and a larger equilibrium level of $h$ as well. If the aggregate supply of $h$ also shifts to the left in response to the higher $y, h$ will significantly rise, while y might not. Either way, $h y$ will increase and so should transfers serving as a compensation for household production.
} 
Operationally, we approximate the wages of commercial domestic workers by the wages of low-skilled female workers in the labor force. ${ }^{8}$ Additionally, because in Denmark more household chores are performed by wives, female partners, and female domestic workers than by husbands and male partners (Bonke et al., 2008), specialization in household work follows traditional gender lines. ${ }^{9}$ Therefore, our testable hypothesis is that higher wages of low-skilled female workers -a proxy for higher costs of domestic services- are likely to raise the likelihood of income pooling among couples with a specialization following traditional gender lines. The price of domestic services should not affect the likelihood of income pooling in non-specialized couples and its impact should be minimal among couples with specialization involving a reversal of gender roles, i.e. couples where men are secondary earners and they work more at household chores than their wives or partners.

\section{Data}

We use data from two sources: the Danish Household Expenditure Survey (HES) and register data. The HES is an ongoing survey of household buying habits covering heterosexual couples, married or not. The survey consists of a self-administered accounting book ('diary') and a questionnaire ('interview'). A supplement administered in the period 1999-2005 asks respondents about their relationships and backgrounds, such as the length of time the respondents have been living together and how they manage their finances. ${ }^{10}$

The register data come from administrative registers and include information on age, income, education, labor market status, civil status, number and age of children, and wages of all

\footnotetext{
${ }^{8}$ Domestic workers are primarily low-skilled women.

${ }^{9}$ Men are primary earners and women secondary earners.

${ }^{10}$ For further details on the data set, see Bonke \& Browning (2010).
} 
household members. ${ }^{11}$ As a proxy for the cost of commercial domestic services we use register data on wages of unskilled females working in the private sector in four different residential areas of Denmark, adjusting for inflation during the six survey years.

In the HES, individuals were asked to indicate the best way to describe their method of organizing their finances. Most households report some form of income pooling, and the vast majority of these households report complete 'income pooling'. ${ }^{12}$ In the following analysis, only those households stating that they pool all their resources (68 percent of all households) are termed 'income pooling' households. Because we are interested in examining whether income pooling is a compensation for household work between primary and secondary earners, we focus our attention on men and women between the ages of 25 and 59. These are ages likely to involve more household production and labor market participation.

We want to compare couples following traditional specialization along gender lines vs. couples who either do not specialize or do not specialize following traditional gender lines. In defining specialized couples along traditional gender lines we consider two criteria for specialization: (1) wife (or female partner) earns less than 50 percent of the couple's earnings, i.e. the wife is the secondary earner; and (2) the wife works less in the labor force than the husband. We refer to the first criterion as the earnings criterion and to the second criterion as the employment criterion of specialization. The employment criterion is met if: (a) the husband is in the labor force and the wife is not, or (b) the husband is employed in the private sector and the wife is employed in the public sector. The assumption behind this employment criterion is

\footnotetext{
${ }^{11}$ If not currently employed, the last yearly wages are used.

${ }^{12}$ Complete income pooling involves choice of the following answer: "'All money is shared: we don't distinguish between 'my' or 'your' money." Alternative answers were: "Some money is regarded as 'my' and some as 'our' money"; "What we earn individually belongs to each of us"; "The husband administers the money, and the wife receives an allowance when she is in need of cash"; "The wife administers the money, and the husband receives an allowance when he is in need of cash"; "The husband administers some of the housekeeping money and the wife administers the rest"; "The wife administers some of the housekeeping money and the husband administers the rest" and "Some other arrangement."
} 
that partners who are less involved in the labor force market perform a greater share of household production. If both work, we look at whether they hold jobs in the private sector or the public sector. In Denmark, relative to jobs in the private sector, public sector jobs typically offer more flexibility and fewer hours of work. Therefore, public sector jobs are often preferred by individuals with a heavier household production load.

A total of 482 couples of the 1472 couples included in the analysis can be considered specialized according to both criteria. To assess whether both the earnings and employment criteria of specialization need to be present in order for income pooling, we also define specialized couples using the earnings and the employment criteria separately. A total of 1089 couples of the 1472 couples included in the analysis can be considered specialized according to the earnings criterion alone and a total of 588 couples can be considered specialized according to the employment criterion.

Basic summary statistics for our samples of study are found in Table 1. Column 1 presents statistics for the couples specialized along traditional gender lines following both criteria of specialization. Column 2 includes all other couples in our sample and serves as our control group. Column 3 includes couples in which the wife earns less than 50 percent of the couple's earnings (earnings criterion of specialization). Finally, column 4 includes couples who are specialized only according to the employment criterion. It can be noted that the likelihood of income pooling does not vary much across the four types of gender specialization. That is not surprising. After all, the price of domestic services is expected to increase the likelihood of income pooling among couples specialized along traditional gender lines, whereas other factors, such as preference for an egalitarian distribution of household income, may increase the likelihood of income pooling among non-specialized couples. 


\section{Methodology}

Our goal is to gain a better understanding of why some couples pool their incomes and others do not. Our main hypothesis is that income pooling is a form of compensation from primary earners to secondary earners, especially if couples are specialized along traditional gender lines according to the earnings and employment criteria. Because we lack data on the amount of home production by each of the partners ( $h$ in our model) and on the value of such work ( $y$ in our model), we assess whether the price of a substitute for home production, as is the case with wages of unskilled female workers, is positively linked to a higher likelihood of income pooling among specialized households. ${ }^{13}$ To test our prediction, we estimate the following logit model: ${ }^{14}$

$$
I P_{i}^{*}=\alpha+\beta^{*} P_{r}^{\text {domestic services }}+X_{i}^{\prime} \chi+\varepsilon_{i}=\mathrm{I}\left(I P_{i}^{*}>0\right)
$$

where: $I P_{i}^{*}$ is the unobserved or latent likelihood of income pooling by the $i$ th couple. The function $\mathrm{I}\left(I P_{i}^{*}>0\right)$ is an indicator function taking on the value "one" if $I P_{i}^{*}>0$ and "zero" otherwise. The variable $P_{r}^{\text {domestic services }}$ captures the average wages of unskilled female workers in the region $r$ where the $i$ th couple resides. Our hypothesis is that $\beta_{1}>0$ and statistically different from zero among specialized couples since its impact is conditional on the existence of some specialization in housework; but not among their counterparts who are not specialized along traditional gender lines.

The vector $X_{i}$ includes a variety of demographic and economic controls, such as age, the educational attainment of both partners and information on the household's non-labor

\footnotetext{
${ }^{13}$ The opposite does not follow. The presence of complete income pooling does not necessarily reflect transfers from male principal earners to female partners doing more of the household work. Income pooling can also reflect feelings of love or egalitarian beliefs.

${ }^{14}$ Results were similar using a probit or linear model specification.
} 
income. We also account for significant age difference between partners, the number of previous partners in the case of men, and for whether the mothers from both partners worked when they were growing up as potentially important factors driving the likelihood of specialization along traditional gender lines and, therefore, the probability of income pooling by couples. Likewise, children -one kind of household public goods (Lam 1988), are included since we expect couples to be more likely to pool their incomes in the presence of more household public goods (Bonke and Uldall-Poulsen 2007). ${ }^{15}$ We also account for children from previous relationships. We estimated our regressions with and without controls for survey year and found that this did not make any difference.

\section{Findings}

Table 2 displays the results from estimating equation (1) as a logit model for various samples of couples. It appears from Table 2 that, as predicted, our proxy for the price of domestic services raises the likelihood of income pooling significantly more among specialized couples (col. 1) in which women earn less and work less in the labor force than among the rest of the sample (col. 2). ${ }^{16}$ In particular, a doubling of the price of domestic services would raise the likelihood of income pooling among specialized couples by approximately 19 percentage points. These results suggest that, as the price of domestic services goes up, the "earnings" of secondary earners from performing household chores, $y h$, increase. However, also as hypothesized earlier on, that price has no impact on income pooling in the rest of the sample. That the price of domestic services -proxied by wages of low-skill women- has no bearing on the likelihood of income pooling among non-specialized couples makes sense too, for among these couples

\footnotetext{
${ }^{15}$ In a similar vein, Klawitter (2008) finds that couples with children are more likely to hold joint accounts than childless couples.

${ }^{16}$ The difference between the effect of price of domestic services in columns 1 and 2 is statistically different from zero at a $5 \%$ level according to a Chow test.
} 
income pooling is less likely to serve as compensation for women's work in household production.

Worth noting is the fact that our proxy for the price of domestic services is also positively linked to a higher likelihood of income pooling among specialized couples in specification (4), which only takes into account specialization according to the employment criterion. A Chow test comparing the effects of the price of domestic services in columns 1 and 4 reveals that income pooling as a form of compensation for performing a greater share of household work is primarily based on the division of labor between men and women following traditional gender roles, regardless of their earnings differential.

Our finding suggests that higher costs of commercial domestic services raise the value of women's household production and, in turn, their bargaining power in marriage and accessibility to her partner's income. Alternatively, access to their partners' income may result from better employment opportunities proxied by higher wages. Better market work prospects may raise all women's bargaining power, regardless of whether they perform household chores or not. However, if higher wages influence women's bargaining power via their labor supply and not via their partners' demand for greater home production, the price of domestic services should raise the likelihood of income pooling among all couples, not just among specialized couples.

In addition to the price of commercial domestic services, a variety of demographic and economic factors appear to be driving the likelihood of complete income pooling in our sample of Danish couples. For instance, we find that older women are more likely to participate in income pooling, which could be a by-product of the longer time they may have been in the relationship or the result of more traditional values. Men are also slightly more likely to support their female partners when women are significantly younger. This effect -captured by the 
coefficient on 'age difference'- is, nevertheless, rather small (statistically significant at times at the 10 percent level) and only suggestive of possible compensating differentials in marriage whereby men compensate women for their older age by transferring more of their income to them (see Grossbard-Shechtman 1993, Woolley 2003).

Also worth noting is how family obligations do impact the likelihood of income pooling, although to varying degrees. For instance, pre-existing family responsibilities -as captured by the presence of children from the woman's previous relationships- lowers the likelihood of income pooling among specialized couples anywhere between 14 and 25 percentage points. ${ }^{17}$ Similarly, other pre-existing family responsibilities captured by the number of previous partners of the male partner at times lower the likelihood of income pooling among specialized couples. Perhaps, men with a larger number of previous partners are more likely to have pre-existing financial obligations that curtail their ability to pool income. This effect is significantly stronger in column (1) than in column (2), possibly because men's prior financial responsibilities are more of a constraint if they also provide financial support to a new wife or female partner. In contrast, current family obligations as captured by the presence of joint children in the household - a form of a public good - generally raises the likelihood of income pooling, particularly when the children are young.

Finally, Table 2 also informs on the likelihood of income pooling among women whose mothers worked when they grew up. We find that women whose mothers worked in the labor market when they were growing up have less access to their husbands' income via income pooling. This holds for specialized couples, regardless of how specialization is defined. Specifically, the likelihood of income pooling in specialized couples drops between 0.09 and

\footnotetext{
${ }^{17}$ Men's children from previous relationships have no impact whatsoever on the likelihood of income pooling, whether couples are specialized or not (results available upon request).
} 
0.14. This could be related to higher productivity in household labor among their female counterparts whose mothers were full time housewives. Alternatively, traditional values could be driving this result.

\section{Robustness Checks}

We further explore if our findings vary by marital status and relationship length. About 64 percent of our sample of 1472 couples is married, while the rest cohabitates. Additionally, about 51 percent of our sample has lived together for at least 10 years. Previous research has shown that, relative to unmarried couples, married couples appear more likely to completely pool their income (Bonke and Uldall-Poulsen 2007) and to hold joint accounts (Woolley 2003, Klawitter 2008). This holds relative to unmarried couples that are either same-sex or differentsex (Klawitter 2008).

Table 3 displays results from carrying out the analysis separately for cohabitating and married couples. Table 4 does the same for couples with up to 9 years of being together and couples with a relationship lasting over 9 years. We focus our attention on the effect of changes in the price of commercial domestic services, which continues to play a substantial role in the likelihood of income pooling among specialized couples. A doubling of the cost of domestic services raises the likelihood of income pooling anywhere between 10 percentage points (Table 4, column 3, the case of couples in shorter-lived relationships with only a difference in earnings) to 28 percentage points (Table 3 , column 5, the case of cohabitating couples specialized according to both the earnings and the employment criteria). We also continue to find that the price of domestic services affects income pooling significantly more among specialized couples in column (1) - particularly via the employment criterion as revealed by the results in column (4)- than among non-specialized couples. 
In sum, after splitting the sample by marital status and relationship length, we continue to find that our proxy for the price of domestic services raises the likelihood of income pooling among specialized couples, but not among non-specialized couples. This reinforces our interpretation that income pooling may serve as a form of compensation from the male partners to their female partners' greater specialization in household production.

\section{Summary and Conclusions}

This paper examines the determinants of complete income pooling. We hypothesize that income pooling depends on the rate at which primary earners compensate secondary earners for this work. In turn, this rate of compensation is expected to be a function of the price of commercial domestic services and of the degree of traditional household specialization. As a result, in our empirical analysis of income pooling reports by Danish couples, we contrast couples specializing along traditional gender roles (couples with female secondary earners) and those who do not. We expect exchanges of household work for monetary transfers among couples specializing along traditional gender lines. Therefore, we expect the price of female domestic services to primarily affect income pooling among couples following a traditional division of labor.

Using survey responses on complete income pooling, we find that the higher the wage of unskilled female workers in the region of residence -our proxy for the price of commercial domestic services- the more couples are likely to completely share their income. This finding is limited to specialized couples along traditional gender lines. Our finding suggests that where women perform home production in excess of what their husbands (or partners) do, they get compensated for this extra work in the form of access to extra income earned by their husbands. In traditional households, the higher the costs of commercial domestic services, the higher 
women's value in markets for household work and, in turn, their bargaining power in marriage and their access to their husbands' earnings via complete income pooling. In contrast, among egalitarian couples or couples following a non-traditional division of labor, the price of domestic services has no effect on income pooling. These are couples where men are not expected to compensate women for work in home production. We had very few couples with reversed domestic roles and found no evidence of women compensating men for their extra work in home production in such instances.

We hope that further work will examine the degree to which income pooling varies with specialization in household production by using more detailed data on the individual time spent in home production while taking account of the endogeneity of their time use patterns with respect to the household's likelihood of income pooling. We also hope that our study can be replicated for other developed and developing economies. 


\section{References}

Apps, Patricia F. and Ray Rees. 1988. "Taxation and the Household." Journal of Public Economics 35:355-369.

Apps, Patricia F. and Ray Rees. 1997. "Collective Labor Supply and Household Production." Journal of Political Economy 105:178-190.

Bonke, J. and Browning, M. (2010). Allocation of expenditures within the household: A New Danish survey. Fiscal Studies 30: 461-481.

Bonke, J., Stratton, L., Lausten, M. and Deding, M. (2008). Intrahousehold Specialization in Housework in the United States and Denmark. Social Science Quarterly. Vol. 89, No 4.

Bonke, Jens and Hans Uldall-Poulsen. 2007. "Why do Families Actually Pool their Income? Evidence from Denmark." Review of Economics of the Household 5:113-128.

Browning, Martin, Francois Bourguignon, Pierre-Andre Chiappori, and Valerie Lechene. 1994. "Income and Outcomes: A Structural Model of Intra-household Allocation." The Journal of Political Economy 102:1067-1096.

Chen, Zhiqi and Frances Woolley. 2001. "A Cournot-Nash Model of Family Decision Making." Economic Journal 111: 722-748.

Chiappori, Pierre-Andre. 1992. "Collective Labor Supply and Welfare." Journal of Political Economy 100: 437-67.

Dobblesteen, Simone and Peter Kooreman. 1997. "Financial management, bargaining and efficiency within the household; an empirical analysis", De Economist, 145: 345-366.

Grossbard-Shechtman, Amyra. 1984. "A Theory of Allocation of Time in Markets for Labor and Marriage." Economic Journal 94:863-82.

Grossbard-Shechtman, Shoshana. 1993. On the Economics of Marriage: a Theory of Marriage, Labor, and Divorce. Boulder, Co., Westview Press.

Klawitter, Marieka.."The Effects of Sexual Orientation and Marital Status on How Couples Hold their Money." Review of Economics of the Household 6(4): 423-446.

Lam, David. 1988. "Marriage Markets and Assortative Mating with Household Public Goods: Theoretical Results and Empirical Implications." Journal of Human Resources 23: 462487.

Lee, Jungmin. 2007. "Marriage, Sharing Rule, and Pocket Money: The Case of Korea."Economic Development and Cultural Change 55(3): 557-582. 
Lee, Jungmin and Mark L. Pocock, 2007. "Intrahousehold allocation of financial resources: evidence from South Korean individual bank accounts." Review of Economics of the Household 5: 41-58.

Lundberg, Shelly and Robert A. Pollak. 1993. "Separate Sphere Bargaining and the Marriage Market." Journal of Political Economy 101:988-1010.

Lundberg, Shelly, Robert Pollak, and Terence Wale. 1997. "Do Husband and Wives Pool Their Resources? Evidence from the U.K. Child Benefit," Journal of Human Resources 32(3): 463-80.

McElroy, Marjorie B. and Mary Jean Horney. 1981. "Nash Bargained Household Decisions : Toward a Generalization of the Theory of Demand." International Economic Review 22: 333-49.

Phipps, Shelley and Peter Burton. 1998. "What's Mine is Yours? The Influence of Male and Female Incomes on Patterns of Household Expenditures.” Economica 65:599-613.

Samuelson, Paul A. 1956. "Social Indifference Curves." Quarterly Journal of Economics 70:122.

Thomas, Duncan. 1990. "Intra-household Resource Allocation: An Inferential Approach." Journal of Human Resources 25:635-664.

Treas, Judith. 1993. "Money in the Bank: Transaction Costs and the Economic Organization of Marriage." American Sociological Review 58(5): 723-734.

Ward-Batts, Jennifer. 2008. "Out of the Wallet and into the Purse: Using Micro Data to Test Income Pooling.” Journal of Human Resources 43:325-351.

Woolley, Frances. 2003. "Control over Money in Marriage." in Shoshana Grossbard-Shechtman (ed.) Marriage and the Economy. New York: Cambridge University Press. 
Table 1

Means and Standard Deviations

\begin{tabular}{|c|c|c|c|c|c|c|c|c|}
\hline \multirow{2}{*}{$\begin{array}{l}\text { Specification } \\
\text { Descriptive Statistic }\end{array}$} & \multicolumn{2}{|c|}{ (1) } & \multicolumn{2}{|c|}{ (2) } & \multicolumn{2}{|c|}{ (3) } & \multicolumn{2}{|c|}{ (4) } \\
\hline & Mean & S.D. & Mean & S.D. & Mean & S.D. & Mean & S.D. \\
\hline Income Pooling & 0.670 & .47 & 0.692 & .46 & 0.687 & .46 & 0.663 & .47 \\
\hline Non-Labor Income & 82.61 & 163.6 & 66.90 & 84.4 & 78.03 & 128.9 & 77.3 & 151.6 \\
\hline Woman's Age & 37.07 & 10.32 & 37.890 & 10.0 & 37.340 & 10.1 & 37.160 & 10.25 \\
\hline Age Difference & 2.199 & 3.13 & 2.315 & 3.27 & 2.313 & 3.25 & 2.211 & 3.12 \\
\hline $\log (\mathrm{P}$ of DS $)$ & 4.850 & .42 & 4.878 & .44 & 4.865 & .43 & 4.843 & .44 \\
\hline Woman's education & 12.400 & 3.31 & 12.340 & 3.54 & 12.300 & 3.36 & 12.390 & 3.42 \\
\hline Man's education & 12.060 & 3.24 & 12.500 & 3.47 & 12.450 & 3.33 & 11.890 & 3.32 \\
\hline Man's Mother Worked & 0.463 & .50 & 0.405 & .49 & 0.429 & .50 & 0.457 & .50 \\
\hline Woman's Mother Worked & 0.442 & .50 & 0.436 & .50 & 0.450 & .50 & 0.434 & .50 \\
\hline Woman's Previous Children & 0.137 & .34 & 0.139 & .35 & 0.129 & .34 & 0.145 & .35 \\
\hline Man's previous partners & 0.309 & .46 & 0.320 & .47 & 0.307 & .46 & 0.320 & .47 \\
\hline Any child 0-1 & 0.064 & .25 & 0.052 & .22 & 0.062 & .24 & 0.065 & .25 \\
\hline Any child 2-15 & 0.461 & .50 & 0.464 & .50 & 0.469 & .50 & 0.461 & .50 \\
\hline Any child 16- & 0.056 & .23 & 0.065 & .25 & 0.066 & .25 & 0.051 & .22 \\
\hline Woman earns less than $50 \%$ & 0 & 0 & .39 & .49 & 0 & 0 & .18 & .38 \\
\hline Man in LF and Woman Not & .32 & .47 & .02 & .13 & .14 & .35 & .29 & .46 \\
\hline Man Private S Woman Public S & .80 & .40 & .13 & .34 & .37 & .48 & .82 & .39 \\
\hline Married & .62 & .49 & .65 & .48 & .64 & .48 & .62 & .49 \\
\hline Duration & 13.2 & 10.37 & 13.36 & 10.16 & 13.28 & 10.13 & 13.08 & 10.31 \\
\hline $\mathrm{N}$ & \multicolumn{2}{|c|}{482} & \multicolumn{2}{|c|}{990} & \multicolumn{2}{|c|}{1089} & \multicolumn{2}{|c|}{588} \\
\hline
\end{tabular}

Notes: Variables are defined in Table A. The various specifications refer to the following samples:

(1) Couple specialized according to the earnings criterion (wife or female partner) earns less than $50 \%$ of the couple's earnings) and the employment criterion (the husband is in the labor force and the wife is not OR the husband is employed in the private sector and the wife in the public sector).

(2) All couples not included in specification (1).

(3) Specialized according to the earnings criterion only.

(4) Specialized couples according to the employment criterion only. 
Table 2

Marginal Effects from a Logit Model of the Likelihood of Income Pooling (t-statistics)

\begin{tabular}{|c|c|c|c|c|}
\hline Specification & (1) & (2) & (3) & (4) \\
\hline $\log (P$ of DS $)$ & $\begin{array}{c}0.188 * * * \\
(3.43)\end{array}$ & $\begin{array}{l}-0.051 \\
(-1.43)\end{array}$ & $\begin{array}{l}0.044 \\
(1.27)\end{array}$ & $\begin{array}{c}0.174 * * * \\
(3.54)\end{array}$ \\
\hline Woman's Age & $\begin{array}{c}0.011 * * * \\
(4.25)\end{array}$ & $\begin{array}{c}0.010 * * * \\
(5.83)\end{array}$ & $\begin{array}{c}0.009 * * * \\
(5.36)\end{array}$ & $\begin{array}{c}0.012 * * * \\
(4.99)\end{array}$ \\
\hline Age Difference & $\begin{array}{l}0.008 \\
(1.05)\end{array}$ & $\begin{array}{c}0.00775^{*} \\
(1.65)\end{array}$ & $\begin{array}{c}0.008 * \\
(1.79)\end{array}$ & $\begin{array}{c}0.012 * \\
(1.72)\end{array}$ \\
\hline Woman's education & $\begin{array}{l}-0.004 \\
(-0.54)\end{array}$ & $\begin{array}{c}-0.014 * * * \\
(-2.90)\end{array}$ & $\begin{array}{c}-0.009 * \\
(-1.88)\end{array}$ & $\begin{array}{l}-0.010 \\
(-1.57)\end{array}$ \\
\hline Man's education & $\begin{array}{c}-0.024 * * * \\
(-3.18)\end{array}$ & $\begin{array}{l}0.006 \\
(1.28)\end{array}$ & $\begin{array}{l}-0.003 \\
(-0.69)\end{array}$ & $\begin{array}{c}-0.018 * * * \\
(-2.72)\end{array}$ \\
\hline Any child 0-1 & $\begin{array}{c}0.136 * * \\
(2.01)\end{array}$ & $\begin{array}{c}0.211^{* * *} \\
(5.34)\end{array}$ & $\begin{array}{c}0.177 * * * \\
(4.40)\end{array}$ & $\begin{array}{c}0.152 * * \\
(2.50)\end{array}$ \\
\hline Any child 2-15 & $\begin{array}{c}0.226^{* * * *} \\
(4.84)\end{array}$ & $\begin{array}{c}0.177 * * * \\
(5.91)\end{array}$ & $\begin{array}{c}0.197 * * * \\
(6.76)\end{array}$ & $\begin{array}{c}0.205^{* * * *} \\
(4.91)\end{array}$ \\
\hline Any child 16- & $\begin{array}{l}0.125 \\
(1.43)\end{array}$ & $\begin{array}{l}0.059 \\
(0.94)\end{array}$ & $\begin{array}{c}0.111 * * \\
(1.98)\end{array}$ & $\begin{array}{c}0.160 * * \\
(2.07)\end{array}$ \\
\hline Woman's Previous Children & $\begin{array}{c}-0.237 * * * \\
(-2.96)\end{array}$ & $\begin{array}{l}-0.102 * \\
(-1.95)\end{array}$ & $\begin{array}{c}-0.141 * * * \\
(-2.72)\end{array}$ & $\begin{array}{c}-0.245 * * * * \\
(-3.44)\end{array}$ \\
\hline Woman's Mother Worked & $\begin{array}{c}-0.143 * * * \\
(-2.99)\end{array}$ & $\begin{array}{l}-0.021 \\
(-0.68)\end{array}$ & $\begin{array}{c}-0.089 * * * \\
(-2.93)\end{array}$ & $\begin{array}{c}-0.133 * * * \\
(-3.05)\end{array}$ \\
\hline Man's Mother Worked & $\begin{array}{l}0.019 \\
(0.41)\end{array}$ & $\begin{array}{l}-0.010 \\
(-0.31)\end{array}$ & $\begin{array}{l}0.026 \\
(0.86)\end{array}$ & $\begin{array}{l}0.015 \\
(0.35)\end{array}$ \\
\hline Man's previous partners & $\begin{array}{c}-0.104^{*} \\
(-1.90)\end{array}$ & $\begin{array}{l}0.008 \\
(0.24)\end{array}$ & $\begin{array}{c}-0.069 * * \\
(-2.02)\end{array}$ & $\begin{array}{l}-0.033 \\
(-0.69)\end{array}$ \\
\hline $\log ($ non-LI) & $\begin{array}{l}0.017 \\
(1.29)\end{array}$ & $\begin{array}{l}0.009 \\
(1.07)\end{array}$ & $\begin{array}{c}0.019 * * \\
(2.36)\end{array}$ & $\begin{array}{c}0.023^{*} \\
(1.96)\end{array}$ \\
\hline $\mathrm{N}$ & 482 & 990 & 1089 & 588 \\
\hline
\end{tabular}

Notes: The figures reported are the Logit model marginal effects. The t-statistics are in parentheses. The regressions include a constant term. * $\mathrm{p}<0.10, * * \mathrm{p}<0.05, * * * \mathrm{p}<0.01$. The various specifications refer to the following samples:

(1) Couple specialized according to the earnings criterion (wife or female partner) earns less than $50 \%$ of the couple's earnings) and the employment criterion (the husband is in the labor force and the wife is not OR the husband is employed in the private sector and the wife in the public sector).

(2) All couples not included in specification (1).

(3) Specialized according to the earnings criterion only.

(4) Specialized couples according to the employment criterion only. 
Table 3

Marginal Effects from a Logit Model of the Likelihood of Income Pooling By Marital Status (t-statistics)

\begin{tabular}{|c|c|c|c|c|c|c|c|c|}
\hline \multirow{2}{*}{$\begin{array}{l}\text { Sub-sample } \\
\text { Specification }\end{array}$} & \multicolumn{4}{|c|}{ Married Couples } & \multicolumn{4}{|c|}{ Cohabitating Couples } \\
\hline & (1) & (2) & (3) & (4) & (1) & (2) & (3) & (4) \\
\hline $\log (\mathrm{P}$ of DS $)$ & $\begin{array}{c}0.141 * * * \\
(2.67)\end{array}$ & $\begin{array}{c}-0.059^{*} \\
(-1.70)\end{array}$ & $\begin{array}{l}0.014 \\
(0.42)\end{array}$ & $\begin{array}{c}0.156 * * * \\
(3.24)\end{array}$ & $\begin{array}{c}0.284 * * \\
(2.47)\end{array}$ & $\begin{array}{l}0.018 \\
(0.24)\end{array}$ & $\begin{array}{c}0.151^{* *} \\
(2.16)\end{array}$ & $\begin{array}{l}0.186^{*} \\
(1.87)\end{array}$ \\
\hline $\mathrm{N}$ & 299 & 640 & 695 & 364 & 183 & 350 & 394 & 224 \\
\hline
\end{tabular}

Notes: The figures reported are the Logit model marginal effects. The t-statistics are in parentheses. The regressions include a constant term. $* \mathrm{p}<0.10, * *$ $\mathrm{p}<0.05, * * * \mathrm{p}<0.01$. The various specifications refer to the following samples:

(1) Couple specialized according to the earnings criterion (wife or female partner) earns less than $50 \%$ of the couple's earnings) and the employment criterion (the husband is in the labor force and the wife is not OR the husband is employed in the private sector and the wife in the public sector).

(2) All couples not included in specification (1).

(3) Specialized according to the earnings criterion only.

(4) Specialized couples according to the employment criterion only. 
Table 4

Marginal Effects from a Logit Model of the Likelihood of Income Pooling By Length of Relationship (t-statistics)

\begin{tabular}{|c|c|c|c|c|c|c|c|c|}
\hline \multirow{2}{*}{$\begin{array}{l}\text { Sub-sample } \\
\text { Specification }\end{array}$} & \multicolumn{4}{|c|}{ Together for Less than 10 Years } & \multicolumn{4}{|c|}{ Together for More than 10 Years or Plus } \\
\hline & (1) & (2) & (3) & (4) & (1) & (2) & (3) & (4) \\
\hline $\log (\mathrm{P}$ of $\mathrm{DS})$ & $\begin{array}{c}0.221 * * \\
(2.43)\end{array}$ & $\begin{array}{l}-0.002 \\
(-0.04)\end{array}$ & $\begin{array}{c}0.097^{*} \\
(1.66)\end{array}$ & $\begin{array}{c}0.165 * * \\
(2.04)\end{array}$ & $\begin{array}{c}0.147 * * * \\
(2.71)\end{array}$ & $\begin{array}{l}-0.063 \\
(-1.61)\end{array}$ & $\begin{array}{l}0.024 \\
(0.63)\end{array}$ & $\begin{array}{c}0.162 * * * \\
(3.15)\end{array}$ \\
\hline $\mathrm{N}$ & 238 & 483 & 532 & 292 & 244 & 507 & 557 & 296 \\
\hline
\end{tabular}

Notes: The figures reported are the Logit model marginal effects. The t-statistics are in parentheses. The regressions include a constant term. $* \mathrm{p}<0.10, * *$ $\mathrm{p}<0.05, * * * \mathrm{p}<0.01$. The various specifications refer to the following samples:

(1) Couple specialized according to the earnings criterion (wife or female partner) earns less than $50 \%$ of the couple's earnings) and the employment criterion (the husband is in the labor force and the wife is not OR the husband is employed in the private sector and the wife in the public sector).

(2) All couples not included in specification (1).

(3) Specialized according to the earnings criterion only.

(4) Specialized couples according to the employment criterion only. 
Table A

Variables and Definitions

\begin{tabular}{ll}
\hline \hline Variables & Definitions \\
\hline $\begin{array}{l}\text { Income Pooling } \\
\text { Woman's Age }\end{array}$ & $\begin{array}{l}\text { Dummy variable equal to } 1 \text { if the couple pools all their income } \\
\text { Wge Difference }\end{array}$ \\
Log (P of DS) & $\begin{array}{l}\text { Husband's age minus wife's age in years, only if husband is at least three years older than wife. } \\
\text { Wage-rate for unskilled women in private sector defined for } 4 \text { regions and per year. Regions are Greater Copenhagen, } \\
\text { towns } 100,000+\text { inhabitants, towns 10, - 99,999, and other. }\end{array}$ \\
$\begin{array}{l}\text { Woman's education } \\
\text { Any child 0-1 }\end{array}$ & Years of educational attainment of the male partner \\
Any child 2-15 & Dears of educational attainment of the female partner \\
Any child 16- & Dummy variable equal to 1 if the couple has any children between the ages of 0 and 1 \\
Woman's Previous Children & Dummy variable equal to 1 if the couple has any children over 16 years old \\
Woman's Mother Worked & Woman having a child from a previous partnership living in the present household \\
Man's Mother Worked & Dummy variable equal to 1 if the female partner's mother worked while she grew up \\
Man's previous partners & Dummy variable equal to 1 if the male partner's mother worked while he grew up \\
Log (non-LI) & Man has had one or more previous partners \\
\hline \hline
\end{tabular}

